\title{
Occipital Intermittent Rhythmic Delta Activity (OIRDA) and Occipital Seizures in an Elderly Patient
}

\section{Yaşlı Bir Olguda Oksipital Nöbetler ve Oksipital İntermittent Ritmik Delta Aktivitesi (OIRDA)}

\author{
Sabire YILDIRIM, ${ }^{1}$ Murat ÇABALAR, ${ }^{2}$ Çiğdem ÖZKARA, ${ }^{3}$ Orhan YAĞIZ, ${ }^{1}$ \\ Filiz MANGA GÜNAYDIN, ${ }^{4}$ Sinan BAHADIR ${ }^{5}$ \\ 'Department of Neurology, Istanbul Training and Research Hospital, Istanbul \\ 2Department of Neurology, Bakirkoy Dr. Sadi Konuk Training and Research Hospital, Istanbul \\ ${ }^{3}$ Department of Neurology, Istanbul University Cerrahpasa Faculty of Medicine, Istanbul \\ ${ }^{4}$ Department of Neurology, Kocaeli Derince Training and Research Hospital, Izmit \\ ${ }^{5}$ Department of Neurosurgery, Bafra State Hospital, Samsun, all in Turkey
}

\section{Summary}

Occipital intermittent rhythmic delta activity (OIRDA) is considered as an electroencephalography (EEG) pattern which is usually seen in children but does not always have pathological significance. The physical examination of a 70-year-old patient who was admitted with complaints of hallucination, headache and falling episodes, revealed just a deficiency of vigilance and concentration. Magnetic resonance imaging of the patient revealed generalized chronic ischemic changes, cerebral atrophy and leukoaraiosis especially prominent in the posterior regions. There was OIRDA presence in the occipital regions in routine EEG examination. Since the patient's symptoms continued despite phenytoin, oxcarbamazepine and topiramate, we replaced topiramate with levetiracetam. Patient's visual illusions and falling episodes diminished following treatment, and also OIRDA highly disappeared in the EEG.

Key words: Epilepsy; migraine; occipital intermittent rhythmic delta activity.

\section{Özet}

Oksipital intermitten ritmik delta aktivitesi (OiRDA), daha çok çocuklarda görülen ve her zaman patolojik anlamı olmayan bir elektroensefalografi (EEG) patterni olarak kabul edilir. Halüsinasyon, baş ağrısı ve düşme atakları ile başvuran 70 yaşında erkek hastanın muayenesinde dalgınlık ve konsantrasyon kaybı vardı. Kraniyal manyetik rezonans görüntülemede yaygın kronik iskemik değişiklikler, serebral atrofi ve özellikle posterior bölgelerde lökoriazis görüldü. Rutin EEG'de oksipital bölgelerde OíRDA vardı. Fenitoin, okskarbazepin ve topiramat ile hastanın şikayetlerinin devam etmesi üzerine topiramat kesilerek levetirasetam eklendi. Tedavi sonrası hastanın halüsinasyonları ve düşme atakları azaldı, EEG'de ise OIRDA büyük ölçüde kayboldu.

Anahtar sözcükler: Epilepsi; migren; oksipital intermittent ritmik delta aktivitesi.

\section{Introduction}

Occipital intermittent rhythmic delta activity (OIRDA) is described as an intermittent, sawtooth shaped, unilateral or bilateral, symmetrical, medium or high amplitude, paroxysmal and regular delta frequency activity occurring in the oc- cipital region during electroencephalography (EEG) monitorization. It increases with hyperventilation and decreases with eye opening and sleep. ${ }^{[1,3]}$ Though OIRDA is suggested to be an interictal EEG finding that is mostly specific to children, it may not always be associated with epilepsy. ${ }^{[2]}$ 
In this report, we present a case of an elderly patient with occipital lobe epilepsy that shows intermittent rhythmic delta activity in the occipital regions.

\section{Case Report}

A 70-year-old male was admitted to our clinic with complaints of colorful bright lights, headache and falling episodes. His medical history revealed that his complaints were present for 6 months. He was having a wide variety of complex hallucinations such as moving shadows during daytime, colorful lights, red walls and bypassing cars. He also described headaches and loss of interest to environment. He was also reported to have 10-15 second-lasting episodes associated with loss of consciousness, falling down and tonic contractions 2-3 times, daily. He slept post-ictally and had no recall of the seizures.

Physical examination of the patient revealed no significant findings other than a deficiency of vigilance and concentration. His blood pressure was $150 / 100 \mathrm{mmHg}$ and blood glucose level was $174 \mathrm{mg} / \mathrm{dl}$. He was on antihypertensive and oral antidiabetic medication. In his neuropsychiatric evaluation, his mini mental test score was within normal limits. Magnetic resonance imaging (MRI) showed 'multiple microangiopathic ischemic foci in cerebral white matter bilater-

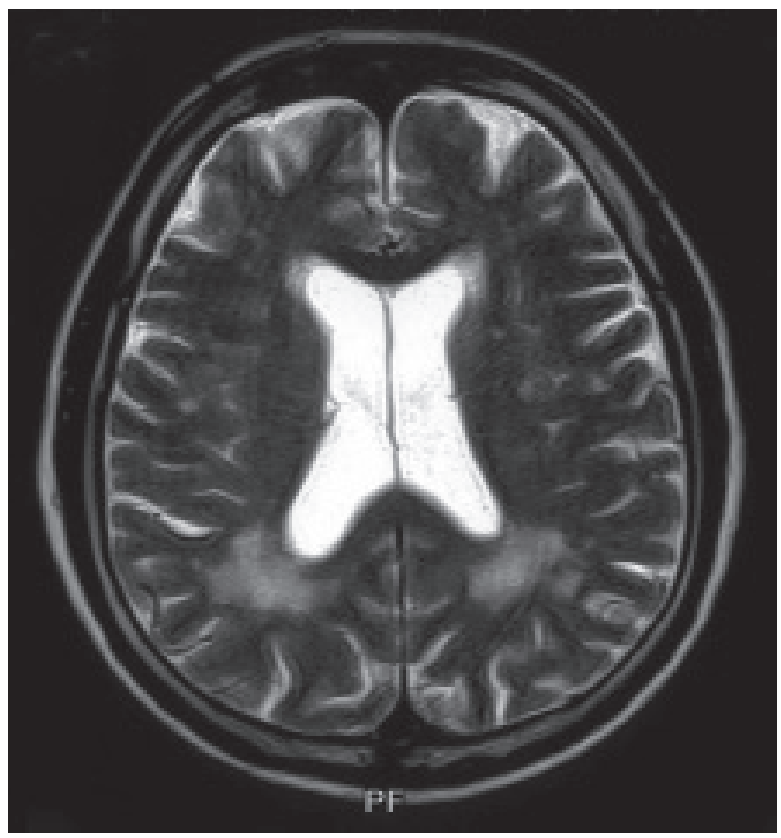

Figure 1. T2 axial section: minimal dilatation of ventricles, cerebral atrophy and posterior leukoaraiosis in MRI. ally, minimal dilatation of third and lateral ventricles' that was considered to be secondary to cerebral atrophy, and 'leukoaraiosis especially prominent in the posterior regions' (Figure 1). Routine EEG examination showed quasi-continuous, bilateral and synchronous long lasting rhythmic, 3-3,5 $\mathrm{Hz}$ delta activity with moderate amplitude and occipital localization. This activity was considered as OIRDA and it ameliorated with eye-opening (Figure 2). The patient was inattentive during the EEG and described visual illusions. The picture suggested a non-convulsive status epilepticus with additional tonic seizures. In order to support or reject this hypothesis IV diazepam (10 mg/IV) was administered during the EEG recording. It resulted with a partial reduction in OIRDA; thus, the procedure was without much benefit for a sound interpretation (Figure 3 ).

Phenytoin up to $400 \mathrm{mg} /$ day was ineffective for the visual seizures and the tonic falling seizures. Oxcarbazepine (600 $\mathrm{mg} /$ day) followed by topiramate ( $200 \mathrm{mg} /$ day) were tried later with no apparent significant improvement in either the clinical or the EEG findings. Upon lack of significant improvement under triple antiepileptic treatment, topiramate was replaced with levetiracetam (1000 mg/day) which resulted with a decrease in the number of the falling seizures and periods of headache. Visual illusions became less frequent and limited to the left eye-field. They were visualized as moving human shadows and disappeared when gazed towards them carefully. During video EEG recording, slow waves were noted to disappear while the eyes were open much less activated by eye closure (Figure 4). All seizures subsided during the later years and, the patient is on oxcarbazepine (600 mg/day) and levetiracetam (1000 mg/day) treatment presently. He is being followed-up for six years without any more complaints.

\section{Discussion}

Occipital slow waves in the EEG with intermittent and rhythmic characteristics, are more common in children, and may be a sign of epilepsy or have no pathological significance at all. ${ }^{[2-4]}$ Although these waves are suggested to be the childhood form of frontal intermittent rhythmic delta activity (FIRDA) which is seen in adults, regarding the clinical correlation they rather resemble temporal intermittent rhythmic delta activity (TIRDA). ${ }^{[2,3]}$ While TIRDA is frequently seen together with temporal lobe epilepsy, FIRDA is reported to be closely assosciated with acute encephalopathy. ${ }^{[5,6]}$ Patients with OIRDA may have, in decreasing frequency, generalized 


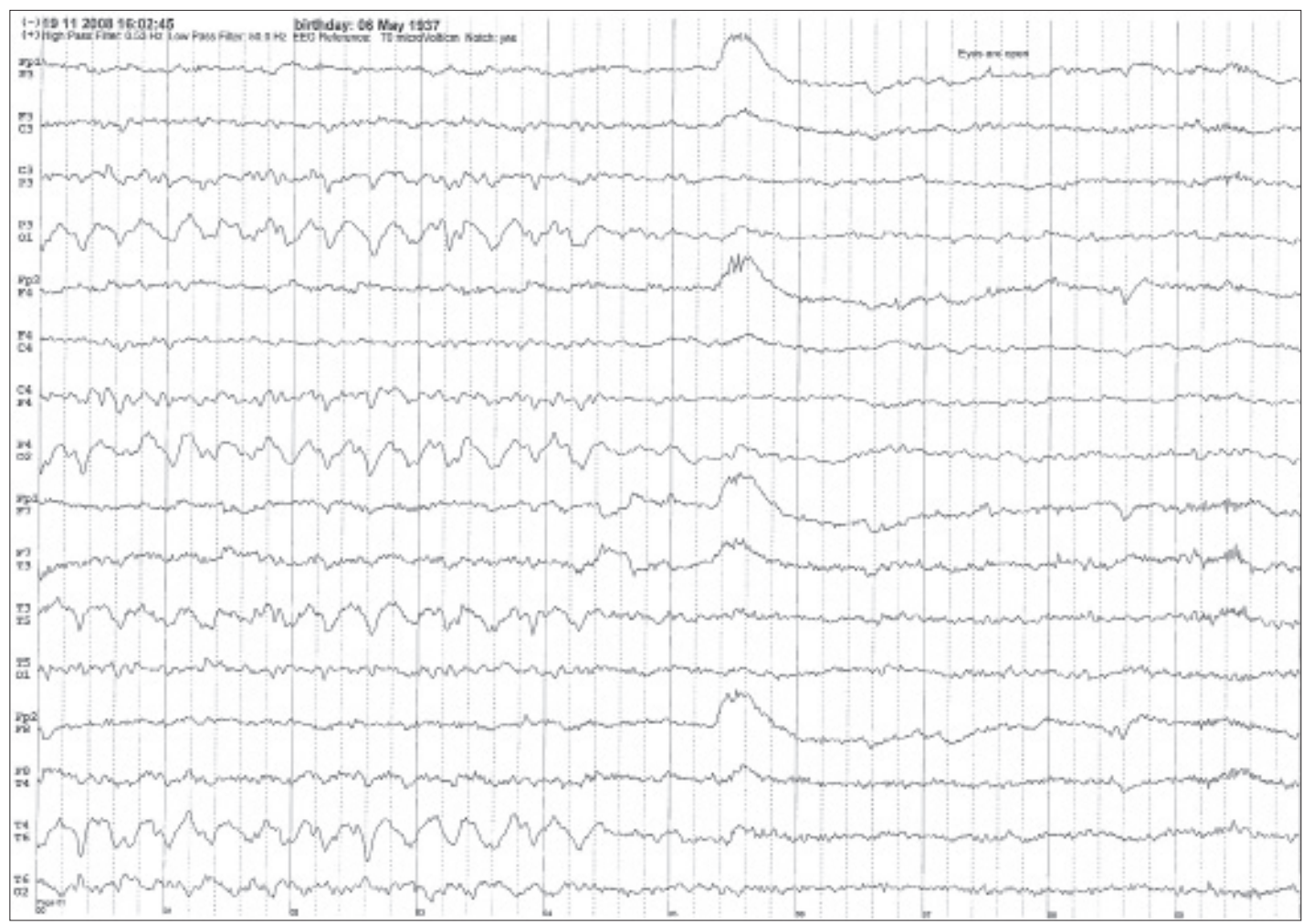

Figure 2. Rhythmic delta activity in routine EEG.

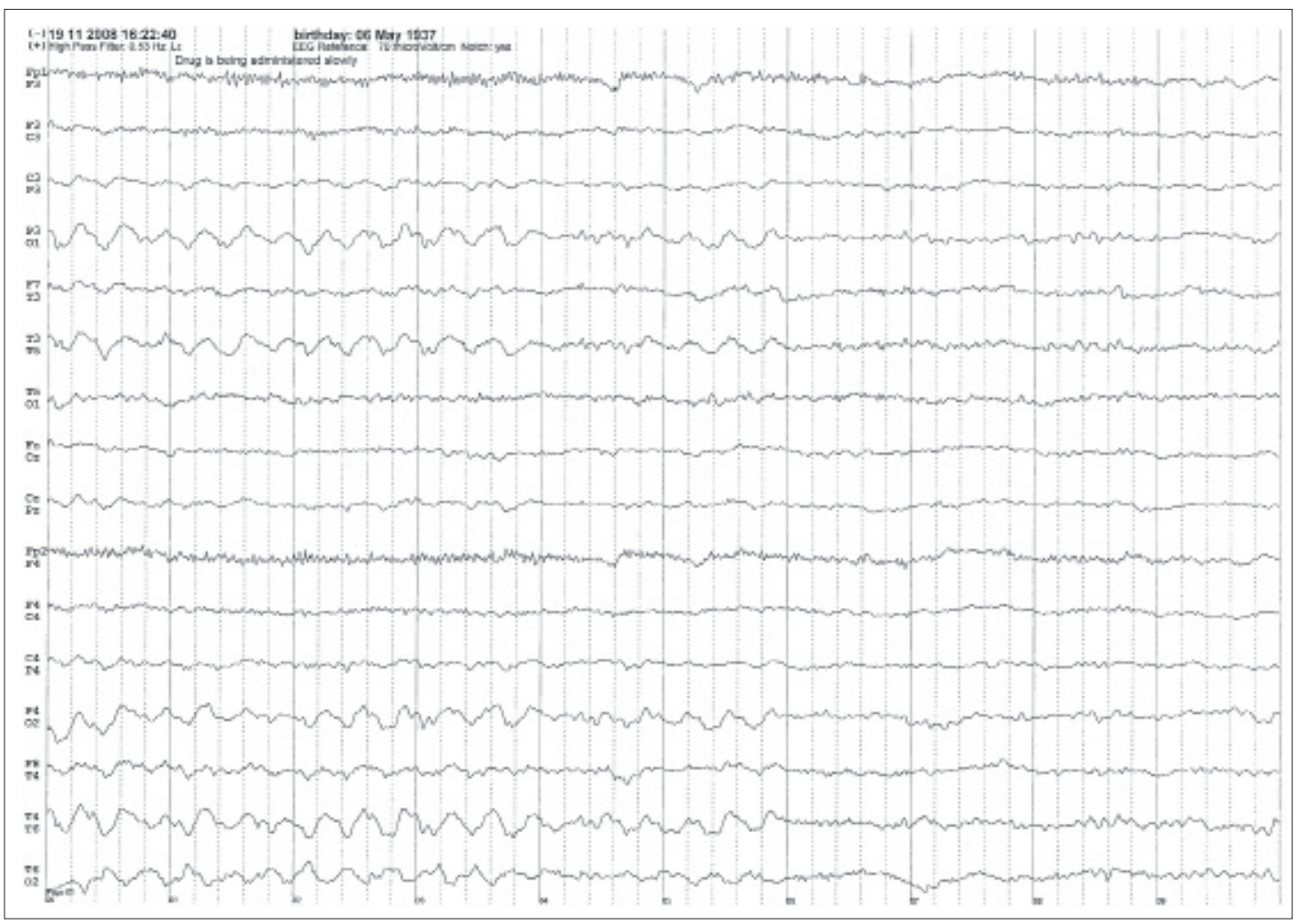

Figure 3. Decrease in rhythmic delta activity following intravenous diazepam administration in routine EEG. 


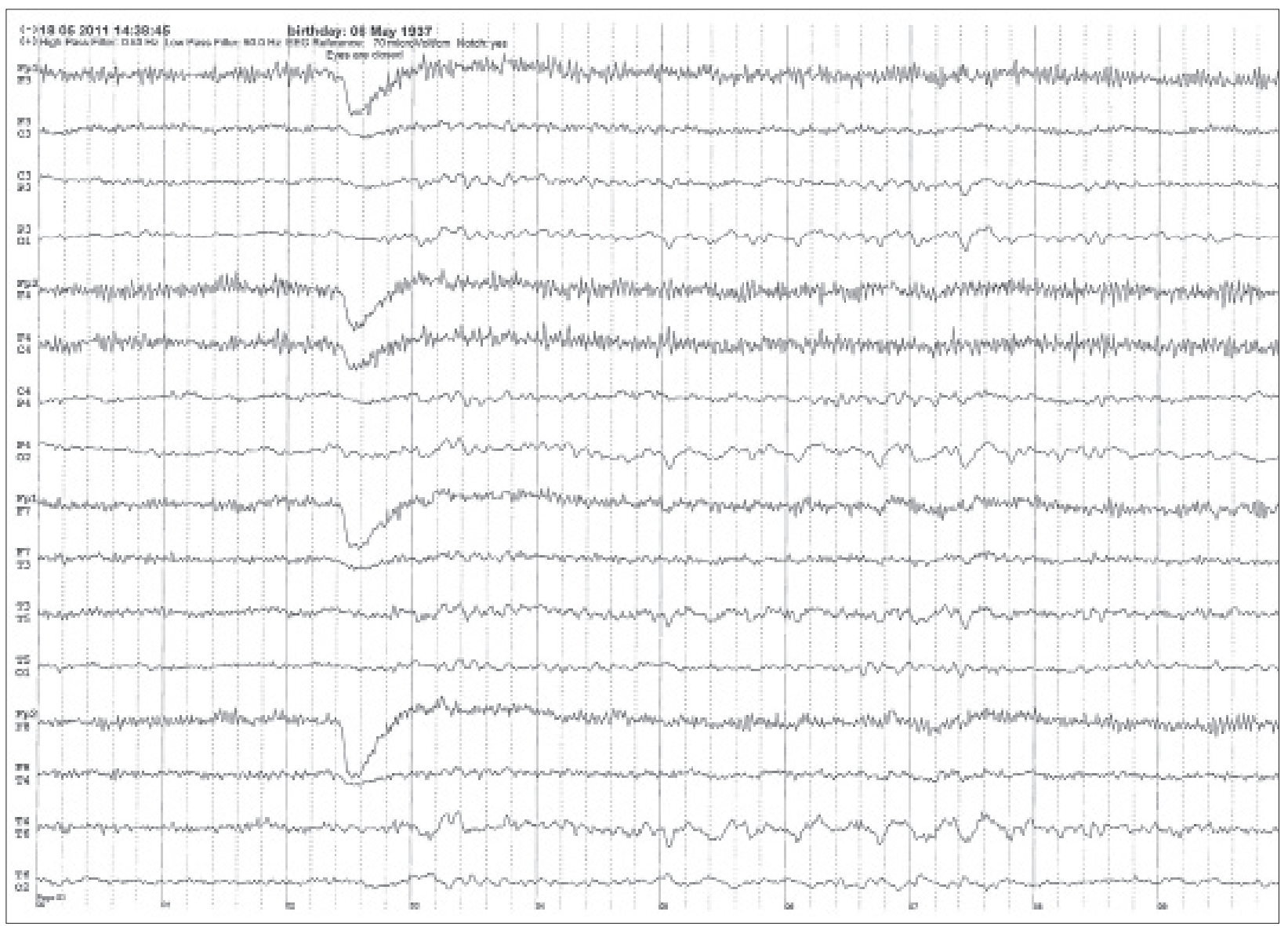

Figure 4. EEG findings after treatment.

tonic-clonic seizures, partial and absence seizures, atonic, tonic and myoclonic seizures. In a limited number of studies that included childhood cases in recent years, it is suggested that OIRDA is an interictal EEG finding, which is mostly specific to children. ${ }^{[2,3,7]}$ Another EEG finding localized to posterior regions is $\mathrm{Pi}$ rhythm which was used by Silbert et al. to identify a form of occipital slow waves which does not have any significance regarding epilepsy. Pi rhythm is a series of short, monomorphic occipital slow waves that is seen only in children and adolescents and occur in the first 2 seconds following eye closure. ${ }^{[4]}$ In our patient, occipital rhythmic waves have occurred either at the same time with or within various intervals following eye closure which ruled out Pi rhythm.

In a comprehensive study on OIRDA by Gullapalli et al. presence of seizures in 69 of 77 patients are reported to be significant when compared to control group. Those were usually presented with generalized convulsions, partial and absence seizures. Apart from a 22-year old young adult, all remaining patients were in childhood age. ${ }^{[3]}$ In another study, Desai et al. studied 31 cases and found that absence seizures were more frequently seen in patients with OIRDA. ${ }^{[8]}$

In our patient, the main clinical picture consisted of periods of frequent and serious visual hallucinations and severe headache. Visual hallucinations may be major symptoms of occipital lobe epilepy as well as migraine aura. ${ }^{[9,10]}$ Visual hallucinations of migraine aura have linear patterns of colorless, black and white sawtooth shapes, whereas, simple visual symptoms in occipital epilepsies have multicolored, circular or spherical patterns. Those symptoms suggest a pathology in the primary visual cortex located in and around the calcarine fissure. Complex visual hallucinations, which involve moving figures resembling human or animal forms, are seen less frequently as compared to simple ones and suggest a temporooccipital involvement. ${ }^{[11-13]}$ It is also reported that severe headache is a frequent 
symptom in occipital lobe epilepsies. ${ }^{[14]}$ Visual hallucinations were in the form of both simple and complex visual symptoms in our patient. Hallucinations seen in occipital lobe epilepsies do not last longer than 1-4 minutes, whereas, hallucinations of migraine aura may last as long as 20150 minutes. Status epillepticus in this case, characterized mainly by visual seizures is differentiated from migraine status by history, presence of tonic seizures and detailed characteristics of visual images. However, it is not easy to accept the present case as a reliable model for status epilepticus with occipital seizures, since no epileptogenic complexes, associating the clinical visual episodes were present in the EEG. ${ }^{[15]}$ In nonconvulsive status epilepticus, continous atypical spike-and-wave, polyspike-andwave and rarely rhythmic bilateral $3 \mathrm{~Hz}$ spike-and-wave complexes are commonly expected. ${ }^{[16]}$ Although, 'atypical' spike-and-wave activity may necessarily not always contain well-formed spikes or sharp-waves during a nonconvulsive status epilepticus, OIRDA in the EEG associating visual illusions and headache episodes seems to provide a more cautious interpretation for this neurological condition with such unique features.

In conclusion, we intended to draw attention to the presence of OIRDA in an elderly patient with occipital lobe epilepsy, although this finding is reported to be more common in childhood.

\section{References}

1. Bora I, Yeni SN. EEG atlasi. Spesifik olmayan EEG bulgulari. Istanbul: Nobel Tip Kitabevi; 2012. p. 367-99.

2. Guilhoto LM, Manreza ML, Yacubian EM. Occipital intermittent rhythmic delta activity in absence epilepsy. Arq Neuropsiquiatr 2006;64(2A):193-7. [CrossRef]

3. Gullapalli D, Fountain NB. Clinical correlation of occipital intermittent rhythmic delta activity. J Clin Neurophysiol 2003;20(1):35-41. [CrossRef]

4. Silbert PL, Radhakrishnan K, Johnson J, Klass DW. The signifi- cance of the phi rhythm. Electroencephalogr Clin Neurophysiol 1995;95(2):71-6. [CrossRef]

5. Buoni S, Zannolli R, Di Bartolo RM, Macucci F, Migliorini L, Sansoni $\mathrm{R}$, et al. Occipital intermittent rhythmic delta activity only following eye closure in atypical CNS Salmonellosis. Clin Neurophysiol 2005;116(8):1768-70. [CrossRef]

6. Geyer JD, Bilir E, Faught RE, Kuzniecky R, Gilliam F. Significance of interictal temporal lobe delta activity for localization of the primary epileptogenic region. Neurology 1999;52(1):202-5.

7. Watemberg N, Linder I, Dabby R, Blumkin L, Lerman-Sagie T. Clinical correlates of occipital intermittent rhythmic delta activity (OIRDA) in children. Epilepsia 2007;48(2):330-4. [CrossRef]

8. Desai J, Mitchell WG, Rosser T, Ramos-Platt L, Ahsan N, Langille $M M$, et al. Clinical associations of occipital intermittent rhythmic delta activity. J Child Neurol 2012;27(4):503-6. [CrossRef]

9. Panayiotopoulos CP. Elementary visual hallucinations in migraine and epilepsy. J Neurol Neurosurg Psychiatry 1994;57(11):1371-4. [CrossRef]

10. Panayiotopoulos CP. Visual phenomena and headache in occipital epilepsy: a review, a systematic study and differentiation from migraine. Epileptic Disord 1999;1(4):205-16.

11. Schäffler L, Karbowski K. Epileptic activity of the occipital lobe. Clinico-electroencephalographic contribution. [Article in German] Fortschr Neurol Psychiatr 1988;56(9):286-99. [Abstract]

12. Schulze-Bonhage A. Differential diagnosis of visual aura in migraine and epilepsy. [Article in German] Klin Monbl Augenheilkd 2001;218(9):595-602. [Abstract] [CrossRef]

13. George D, Bernard P. Complex hallucinations and panic attacks in a 13-year-old with migraines: the alice in wonderland syndrome. Innov Clin Neurosci 2013;10(1):30-2.

14. Tokay T, Komsuoglu SS. Epileptik auralar. Düşünen Adam 2004;17(3):162-67.

15. Walker MC, Smith SJ, Sisodiya SM, Shorvon SD. Case of simple partial status epilepticus in occipital lobe epilepsy misdiagnosed as migraine: clinical, electrophysiological, and magnetic resonance imaging characteristics. Epilepsia 1995;36(12):1233-6.

16. Kaya D, Yalınay P, Arman F. Nonkonvulsif status epileptikusta tanı, klinik özellikler ve tedaviye direnç sıklığı. Epilepsi 2010;16(3):153-160. 